\title{
About the Use of Pectin from Wild Berries Pomace in the Marmalade Recipes
}

\section{Marina N. Shkolnikova'}

${ }^{1}$ Ural State University of Economics, Ekaterinburg, Russian Federatio, e-mail: shkolnikova.m.n@mail.ru

Keywords:
cowberry;
marmalade;
pomace;
pectin;
structure forming
agent;
quality indicators;
functional properties

\begin{abstract}
The rapid development pace of the functional food industry stimulates researchers to a more detailed study of plant raw materials as an ingredient that demonstrates physiological activity in food recipes. In this regard, cowberries pomace (Vaccínium vítis-idaéa L.) obtained after the liquid phase separation is a prospective raw material primarily due to the bioactive component presence: dietary fibers, vitamins, organic acids, minerals. Thus, an integral part of low-waste and non-waste technologies is the bioconversion issue of secondary raw materials, particularly pulp and meal. Authors separated the pectin sample by the method of acid extraction hydrolysis from cowberries pomace and studied its technological properties and quality indicators. On this basis researchers recommended to use cowberry pectin as a structure forming agent while producing fruit marmalade samples. They examined freshly produced marmalade samples for compliance with the requirements of regulatory documents in comparison with the control sample with commercial citrus pectin as structure forming agent. The commercial pectin substitution in the recipe for the pectin sample obtained from cowberry pomace improves the jelly organoleptic characteristics and increases its functional properties.
\end{abstract}

\section{К возможности использования пектина из выжимок дикорастущих ягод в рецептуре мармелада}

\section{М.Н. Школьникова ${ }^{1}$}

'Уральский государственный экономический университет, г. Екатеринбург, Российская Федерация, e-mail:shkolnikova.m.n@mail.ru

Ключевые слова:
брусника
обыкновенная;
мармелад;
выжимки;
пектин;
структурообразова-
тель;
показатели качества;
функциональные
свойства

\section{Реферат}

Развитие индустрии функциональных продуктов питания стимулирует исследователей к более детальному изучению растительного сырья в качестве ингредиента, проявляющего физиологическую активность в рецептурах пищевых продуктов. Выжимки ягод брусники обыкновенной (Vaccínium vítis-idaéa L.), получаемые после отделения жидкой фазы, представляются перспективным сырьем, в первую очередь, благодаря наличию в их составе таких биоактивных компонентов, как пищевые волокна, витамины, органические кислоты, минеральные вещества. Неотъемлемой частью малоотходных и безотходных технологий является биоконверсия вторичных сырьевых ресурсов - жомов и шротов. Из выжимок ягод брусники обыкновенной методом кислотного гидролиза-экстракции выделен образец пектина, результаты изучения технологических свойств и показателей качества которого позволили предложить его к использованию как структурообразователь при получении образцов фруктового мармелада. Свежевыработанные образцы мармелада исследованы на соответствие требованиям нормативных документов в сравнении с контрольным 
образцом, структорообразователем в котором послужил коммерческий цитрусовый пектин. Установлено, что замена в рецептуре коммерческого пектина на образец пектина, полученный из выжимок ягод брусники обыкновенной, улучшает органолептические показатели мармелада и повышает его функциональные свойства.

Для цитирования: Школьникова М.Н. К возможности использования пектина из выжимок дикорастущих ягод в рецептуре мармелада // Индустрия питания/Food Industry. 2019. T. 4. № 1. С. 81-86. DOI 10.29141/2500-1922-2019-4-1-9

\section{Introduction}

Fruit and berry raw materials are the most important sources of biologically active substances formed as secondary metabolites in the life of plant cells. Due to the high taste and the presence of components doing physiological activity, cowberries which feature is to retain properties even while boiling arouse particular interest. In response to the organic acid presence, especially benzoic, berries can be stored for a long period of time without changing the main quality indicators [1]. Traditionally, a man uses cowberries to make jams, marmalade, jelly, mousses, fruit drinks and juices, liqueurs and infusions, sauces, pie fillings, as well as eats fresh and soaked. While producing beverages and extracts from cowberries the large amount of pomace consisting of fruit pulp, seed and rind, rich in pectin are yielded. Manufacturers widely use pectin obtaining gelling properties in the food industry as a structure and functional food ingredient. The physiological activity range of pectin is well-studied and quite diverse. It demonstrates immunomodulatory, gastroprotective, anticarcinogenic and/or anti-metastatic effects, encourages toxic elements clearance, acquiring bacteriostatic and bactericidal activity against a number of pathogenic and opportunistic pathogenic bacteria, encourages better absorption of calcium and magnesium ions [2; 3].

In modern economic embargo and import substitution conditions the use of local raw materials and waste products including wild ones plays an important role. According to experts, the cowberries reserves amount (on average) about $193.81 \mathrm{~kg} / \mathrm{ha}$ [4]. In this regard, the research purpose is to study the possibility of using pectin from cowberry pomace in the fruit marmalade recipes.

Materials and Methods

The study objects are cowberries pomace (Vaccínium vítis-idaéa L.) and obtained from its pectin and fruit marmalade samples: № 1 - control, № 2 experimental (where the cowberry pectin is a structure-forming agent), studied by standard organoleptic and physical and chemical methods.

Discussion of Results

Pomace acquired from the cowberry is a lumpy mass dark orange in color with a pleasant sweet and sour taste, specific for these berries pronounced fla- vor. Quality analysis of the cowberry pomace shows the practicability of its use as a raw material for the pectin substances extraction, as the pectin content in it is more than $2 \%$, that is typical for fruit and berry raw materials (2-7\%). There are the experimental values of physical and chemical parameters of cowberry pomace:

Moisture WT, W, \%

Organic Acids WT, \%, in Terms of Malic Acid $3.50 \pm 0.1$

Extractives WT, \%

Reducing Sugars WT, \%

Pectin Substances WT, \%

$2.65 \pm 0.05$

Anthocyanin WT, \%

Benzoic Acid WT, mg \%

$92.00 \pm 0.2$

Researchers obtained experimental pectin samples from cowberry pomace by the ordinary method developed earlier in [5] that consists in the biomass extraction by a fivefold amount of dilute oxalic acid solution at a temperature of not more than $70^{\circ} \mathrm{C}$ for 4 hours. After the extract separation from the solid fraction the authors subsided it by the ethyl alcohol. The flocculated pectin was filtered and dried on air to a humidity of 5-6\%. The pectin yield (with an extraction coefficient of $68 \%$ ) was $1.8 \pm 0.05 \%$.

The produced pectin sample appears as a powder of dark orange color, with sweet and sour taste and faint flavor of cowberries. The pectin color is due to the presence of anthocyanins in the raw material amounted to $0.17 \%$ (the transition coefficient from pomace $-43 \%$ ). The table 1 demonstrates physical and chemical parameters of the pectin experimental sample in comparison with the commercial sample taken as a control are given in.

The data in the table 2 demonstrates that the physical and chemical parameters of the test sample of cowberry pectin meet the requirements of GOST 29186-91. It contains anthocyanin pigments (mainly glycosides of peonidin and cyanidin [6]) and minerals. The mass fraction of ash insoluble in $10 \%$ hydrochloric acid solution is $0.01 \%$, which is acceptable for the food use of an ingredient of plant origin, especially considering the dosage. Due to the fact that the mass fraction of benzoic acid for marmalade is a normalized indicator authors determined its amount in the cowberries extracts and the resulting pectin sample. 
Table 1. Physical and Chemical Parameters of the Experimental Pectin Sample Таблица 1. Физико-химические показатели экспериментального образца пектина

\begin{tabular}{|c|c|c|c|}
\hline Indicator & $\begin{array}{c}\text { (According } \\
\text { to GOST 29186-91) }\end{array}$ & $\begin{array}{l}\text { Experimental } \\
\text { Sample }\end{array}$ & $\begin{array}{l}\text { Commercial } \\
\text { Sample }\end{array}$ \\
\hline Moisture WT, \% & not more than 10.0 & $5.3 \pm 0.1$ & \\
\hline WT of Fibrous Fractions Particles Larger than 0.5 mm, \% & not more than 20.0 & not detected & not detected \\
\hline Extraneous Bodies Visible to the Naked Eye & prohibited & absent & absent \\
\hline $\mathrm{pH}$ of $1 \%$ Solution & & 3.6 & 3.0 \\
\hline Total Ash WT, \% & \multirow{4}{*}{ not restricted } & $1.51 \pm 0.02$ & $2.21 \pm 0.02$ \\
\hline Ash WT Insoluble in $10 \% \mathrm{HCl}, \%$ & & $0.010 \pm 0.003$ & $0.060 \pm 0.001$ \\
\hline Benzoic Acid WT, mg \% & & $12.0 \pm 0.2$ & - \\
\hline Anthocyanin WT, \% & & $0.17 \pm 0.01$ & - \\
\hline
\end{tabular}

Table 2. Uronide Component Characteristics of Pectin Samples, \%

Таблица 2. Уронидная составляющая образцов пектина, \%

\begin{tabular}{|l|c|c|}
\hline \multicolumn{1}{|c|}{ Indicator } & \multicolumn{2}{c|}{ Cowberry Pectin } \\
\hline Esterification Degree & $67.7 \pm 0.1$ & $68.0 \pm 0.1$ \\
\hline Pectic Acid WT & $36.7 \pm 0.1$ & $36.5 \pm 0.1$ \\
\hline Free Carboxyl Groups WT & $4.38 \pm 0.01$ & $4.18 \pm 0.01$ \\
\hline Bound Carboxyl Groups WT & $11.03 \pm 0.01$ & $11.53 \pm 0.01$ \\
\hline Metaxylene Groups Content & $8.18 \pm 0.01$ & $8.40 \pm 0.01$ \\
\hline Acetyl Groups Content & $0.033 \pm 0.001$ & $0.179 \pm 0.001$ \\
\hline
\end{tabular}

The main indicators characterizing pectin as a structure forming agent are the degree of esterification, the methoxyl and acetyl groups content. The table 2 consists of the uronide component study results of the experimental cowberry pectin and commercial citrus pectin samples.

The determining indicator of the pectin technological properties is the esterification degree. For cowberry pectin it is $67.7 \%$ and is comparable with the value calculated for the commercial sample. According to the GOST 29186-91' tin belong to highly esterificated pectin type B with the average tankage (67-69\%). It capable of forming a solid elastic structure in the presence of sugar and acid with high content of solids in the product (not less than $50 \%$ ).

The pectin molecule is a polysaccharide constructed from monomeric units of polygalacturonic (pectic) acid, the content of which in the test sample depends on the gelling ability. When free carboxyl groups are over ester groups gel forming ability of pectin decreases while binding increases. Cowberry pectin with a low content of pectic acid (36.7 \%) is a good gelling agent. The content of methoxyl groups is $8.18 \%$ that is comparable to the commercial sample of $8.40 \%$, therefore, the solubility and gelling

1ГОСТ 29186-91. Пектин. Технические условия. Введен вдействие: 01.01.1993. Дата актуализации описания: 01.01.2019. [GOST 29186-91. Pectin. Technical Requirements. Date of Validity: 01.01.1993. Data of Description Actualization: 01.01.2019] ability of cowberry pectin will be within the control indicators. The more methoxyl groups, the better soluble pectin and lower its complexing ability. For gelling ability of pectin researchers determined the normal range of metaxylene groups below $7 \%$.

The weight fraction of acetyl groups in cowberry pectin is 2.5 times less than in the control sample, which indicates its better gelling ability. Since with an increase in the acetyl groups content, the ability of pectin to gelation decreases. Usually acetyl number varies widely: from hundredths of a percent to $2.5 \%$ and the recommended value for jelly forming pectin is $1 \%^{2}$. Thus, the chemical structure features of cowberry pectin contribute to the gel formation characterized by a significant viscosity comparable to commercial pectin used in confectionery production in marmalade recipes.

Along with the chemical structure features of the functional pectin molecule groups, its jelly forming ability depends on the molecular weight and the degree of polymerization. For cowberry pectin, these indicators are determined by an indirect method based on the characteristic viscosity and amount to $7,9951.42 \mathrm{~g} / \mathrm{mol}$ and 454 , respectively. Figure 1 shows the jelly appearance obtained to determine

\footnotetext{
${ }^{2}$ Katasonova O.Yu., Tipsina N.N., Tsuglenok N.V.. Sposob Polucheniia Pektina [Pectin Production Method]. Patent of the RF № 2329663. Patent Owner: FGBOU VPO Krasnoiarskii Gosudarstvennyi Agrarnyi Universitet. Declared: 24.10.2006. Published: 27.07.2008. Bulletin № 21.
} 
the jelly forming ability of pectin from cowberry pomace in the presence of sugar and citric acid.

A jelly sample has a cubic form keeping it within the shelf life. The elasticity and density values of pectin jelly were $82 \mathrm{n} / \mathrm{m}^{2}$ and $1.56 \mathrm{~g} / \mathrm{cm}^{3}$ that confirms its good gelly forming ability and the possibility of using pastille and marmalade products in the recipes, instead of expensive imported pectin (citrus or apple).

All countries allowed the pectin use as food additives. In accordance with the recommendations of JECFA, the permissible pectin concentration as a dietary supplement is not limited. In accordance with the Sanitary Regulations and Standards 2.3.2.129303 "Hygienic Requirements for the Food Additives Use" (Annex. 3, paragraph 3.6) pectin is used in food according to process instruction. The recommended daily intake of pectin in the diet of an adult is 5-6 $\mathrm{g}$.

Researchers developed experimental marmalade samples on the basis of the primary recipes considering the laboratory conditions [7]. They selected empirically the composition and ingredients ratio, based on the literature data on the optimal amount of sugar, acid and solids content in the finished product - at least $70 \%$ for highly esterified pectin
[7]. The table 3 demonstrates it (excluding losses).

Researchers cooked marmalade mass in the traditional way. A distinctive feature is the "dry" dosing of pectin in a mixture with $1 / 10$ of the granulated sugar norm in the apple and glucose mixture. After adding the entire amount of pectin, a man stirred the components at a temperature of $80-90{ }^{\circ} \mathrm{C}$ for 2 minutes, then introduced the remaining recipe amount of sugar and boiled on low heat until the mixture was heated to a temperature of $106^{\circ} \mathrm{C}$. At this temperature, researchers introduced a solution of citric acid and sodium lactate, boiled during 30 seconds, thoroughly mixed and slowly cooled to form a jelly ( $3 \mathrm{~h})$. Authors examined received marmalade quality by organoleptic, physical and chemical and microbiological parameters against GOST 6442-2014 and compared with a control sample on commercial pectin.

There is a marmalade appearance and structure in the figure. The prototype marmalade sample shape is correct, square, with a clear outline, without deformation. Its fracture is semi-transparent, slightly cloudy, not glazed. The consistency is gelatinous, dense, amenable to knife cutting. This sample has delicate taste, common flavor typical for apple mar-
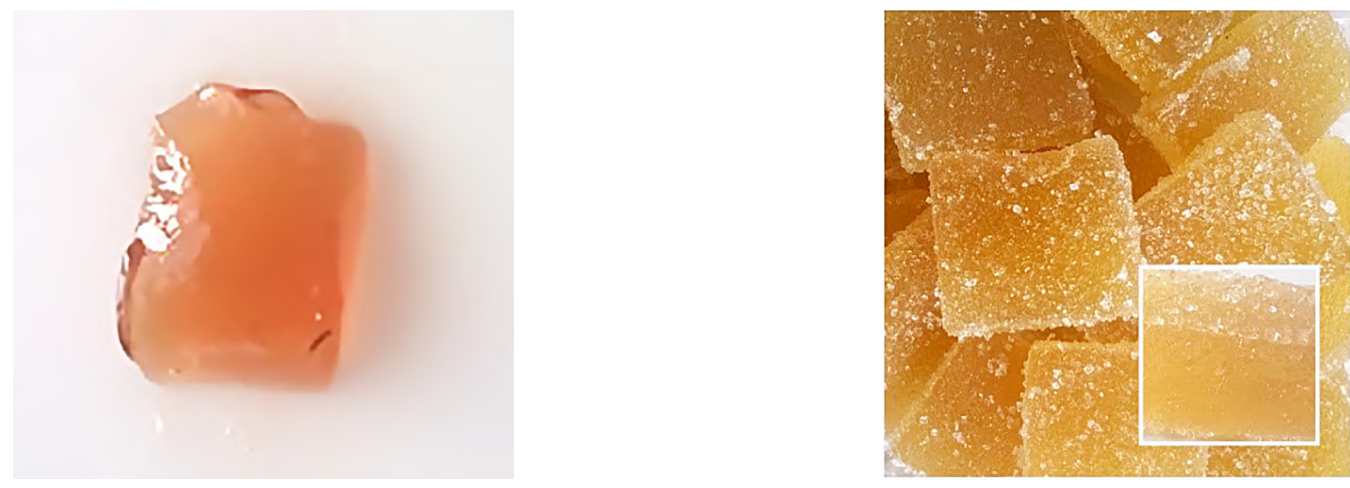

Photos of the Appearance of Cowberry Pectin Jelly and Sliced Fruit Marmalade Obtained from It Фотографии внешнего вида желе брусничного пектина и полученного из него фруктового резаного мармелада

Table 3. Recipe of the Experimental Sample Marmalade Таблица 3. Рецептура экспериментального образца мармелада

\begin{tabular}{|l|c|c|c|}
\hline \multicolumn{1}{c|}{ Indicator } & Cowberry Pectin & \multicolumn{2}{c|}{ Amount per 100 kg of Finished Marmalade, kg } \\
\cline { 3 - 4 } & & Live Weight & in DM \\
\hline Natural Apple and Peach Juice with Pulp & 12.00 & 23.43 & 2.81 \\
\hline Glucose Syrup & 78.00 & 33.34 & 26.01 \\
\hline Sugar & 99.85 & 43.75 & 43.69 \\
\hline Stodgy Apple Puree & 15.00 & 8.88 & 1.33 \\
\hline Cowberry Pectin & 95.00 & 2.13 & 2.02 \\
\hline Citric Acid & 50.00 & 1.02 & 0.51 \\
\hline Sodium Lactate & 40.00 & 1.02 & 0.41 \\
\hline Total & - & 113.57 & 76.78 \\
\hline Output & 68.7 & 100 & - \\
\hline
\end{tabular}


malade with honey notes; the surface is dredged with sugar. The table 4 illustrated the values of physical and chemical parameters.

As can be seen from the table 4 , the mass moisture fraction of marmalade prototypes is $15.4 \%$ (for control) and $10.6 \%$ (for experimental), varying in the GOST 6442-2014 established range. The lower humidity of the cowberry pectin sample is in good agreement with the tasting results - its consistency is less sticky, well cut with a knife. Ash content is an important indicator of the food quality, which includes raw materials and ingredients of plant origin. The actual values of this indicator are within the regulated limits and do not exceed $0.10 \%$. The most important indicator in assessing the marmalade quality is the mass fraction of fruit raw materials. The fruit part in the samples exceeds the established norm due to the use of stodgy apple puree in the recipe. The value of this indicator is slightly higher for the experimental sample of crowberry pomace pectin, which is probably due to the lower humidity of this sample and greater water-retaining capacity of cowberry pectin.

The current GOST 6442-2014 does not regulate the pectin weight fraction. However, the weight fraction of this ingredient should not exceed $2.7 \%^{2}$. The optimal value is the interval from $1 \%$ to $2 \%$, since gels with good consistency are formed at this value, without changing the process duration of the gel formation. With an increase in the pectin

1ГОСт 6442-2014. Мармелад. Общие технические условия. Введен в действие: 01.01.2016. Дата актуализации описания: 01.01.2019. [GOST 29186-91. Marmalade. General Technical Requirements. Date of Validity: 01.01.2016. Data of Description Actualization: 01.01.2019].

${ }^{2}$ Kazantsev E.V., Kondratev N.B., Rudenko O.S., Kerbi O.A., Aksenova L.M.. Sposob Opredeleniia Massovoi Doli Pektinov v Marmelade [Method of Determining the Pectin Weight Fraction in Marmalade]. Patent of the RF № 2492468. Patent Owner: Rossiiskaia Akademiia Selskokhoziaistvennykh Nauk, Gosudarstvennoe Nauchnoe Uchrezhdenie Nauchno-Issledovatelskii Institut Konditerskoi Promyshlennosti (GNU NIIKP). Declared: 19.06.12. Published: 10.09.13. Bulletin № 25. concentration, the plastic strength of the gels increases leading to the marmalade mass squeezing, worsening the consistency and increasing the syneresis probability [8]. Anthocyanins are minor food components; which content is also not regulated by GOST 6442-2014. It gives the food a particular color and functional properties. Researchers found benzoic acid in pectin samples in trace amounts, despite its relatively high content in cowberry pomace due to the pectin dosage (1.5\%), in which its amount is about $12 \mathrm{mg}$.

While determining the microbiological parameters authors confirmed that freshly processed marmalade samples met the requirements of TR CU 021/2011.

Thus, marmalade produced with the use of a pectin sample from cowberry pomace as a gelling agent meets the requirements of GOST 6442-2014, and its taste, smell and color exceed the control sample. Additionally, the studied marmalade has no synthetic dyes and flavors, which increases its consumer advantages.

A man determined the organic acids and minerals concentration by capillary electrophoresis. Macronutrients as potassium $(2.98 \mathrm{mg} / \mathrm{l})$, sodium $(1.39 \mathrm{mg} / \mathrm{l})$, magnesium $(0.33 \mathrm{mg} / \mathrm{l})$ are the most important nutritional value components of confectionery products made by using vegetable raw materials, and the acidity of the marmalade mass (malic acid $8.28 \mathrm{mg} / \mathrm{l}$, citric acid $23.02 \mathrm{mg} / \mathrm{l}$ ) not only contributes to the pleasant taste with "sour", but is a necessary condition for the gel formation.

\section{Conclusion}

The pectin sample obtained from the pomace of cowberry meets the requirements of GOST 2918691, contains phenolic substances and microelements. The esterification degree was $67.7 \%$, which allowed to include cowberry pectin to the high-ester pectin with average tankage of type $B$ used in production technology of pastille and marmalade. The values of the pectin jelly elasticity and densi-

Table 4. Physical and Chemical Characteristics of the Marmalade Samples

Таблица 4. Физико-химические показатели образцов мармелада

\begin{tabular}{|c|c|c|c|}
\hline \multirow{2}{*}{ Indicator } & \multicolumn{3}{|c|}{ Value } \\
\hline & $\begin{array}{l}\text { Restricted (according } \\
\text { to GOST 6442-2014) }\end{array}$ & $\begin{array}{l}\text { Actual for the Sample } \\
\qquad \text { № } 1\end{array}$ & $\begin{array}{l}\text { Actual for the Sample } \\
\text { № } 2\end{array}$ \\
\hline Moisture WT, \% & $9.00-24.00$ & $15.4 \pm 0.2$ & $10.6 \pm 0.2$ \\
\hline $\begin{array}{l}\text { Ash WT Insoluble in } 10 \% \mathrm{HCl} \\
\text { Solution, \%, not more }\end{array}$ & 0.10 & $0.08 \pm 0.01$ & $0.06 \pm 0.01$ \\
\hline Fruit Puree WT, \%, not more & 30.0 & $32.0 \pm 1.5$ & $42.5 \pm 1.5$ \\
\hline Total Sulfurous Acid WT, \%, not more & 0.01 & 0.004 & 0.003 \\
\hline Benzoic Acid WT, \%, not more & 0.07 & not c & cted \\
\hline Pectin WT, \%, not more & 2.7 & 1.8 & 1.5 \\
\hline Anthocyanin WT, \% & not restricted & $0.026 \pm 0.002$ & $0.030 \pm 0.002$ \\
\hline
\end{tabular}


ty were $82 \mathrm{n} / \mathrm{m} 2$ and $1.56 \mathrm{~g} / \mathrm{cm} 3$, which confirms its good jelly forming ability and the possibility of using in pastille and marmalade recipes instead of expensive imported pectin.

Authors obtained the experimental marmalade samples made of cowberry pomace pectin as a structure forming agent. When assessing the quality of freshly processed marmalade samples researchers found that it met the requirements of GOST 64422014 for all regulated organoleptic and physical and chemical parameters, and requirements TR CU $021 / 2011$ for microbiological indicators. The pectin amount in the test sample was $1.5 \%$, the concen-

\section{Bibliography}

1. Safronova, I.V.; Goldina, I.A.; Gaidul, K.V.; Kozlov, V.A. Osobennosti Khimicheskogo Sostava Brusniki Obyknovennoi i Perspektivy ee Primeneniia v Meditsine i Zdorovom Pitanii [Chemical Composition Features of the Cowberries and Prospects of its Application in Medicine and Healthy Nutrition]. Innovatsii i Prodovolstvennaia Bezopasnost. 2015. № 4. P. 63-73.

2. Zlobin, A.A.; Martinson, E.A.; Ovodov, Yu.S. Antioksidantnaia i Antimikrobnaia Aktivnost Pektinov Riada Rastenii Evropeiskogo Severa Rossii [Antioxidant and Antimicrobial Pectins Activity of a Number of Plants In the European North of Russia] Izvestiia Komi nauchnogo tsentra UrORAN. 2011. Vypusk 3 (7). P. 33-37.

3. Ovodov, Yu.S. Sovremennye Predstavleniia 0 Pektinovykh Veshchestvakh [Modern Ideas about Pectin Substances]. Bioorganicheskaia Khimiia. 2009. № 3 (35). P. 293-310.

4. Malinovskikh, A.A.. Vliianie Urovnia Osveshchennosti pod Pologom Lesa na Urozhainost Brusniki v Usloviiakh Sredne-Obskogo Bora Altaiskogo Кraia [Impact of the Illumination Level under the Forest Canopy on the Yield of Cowberries in the Conditions of the Middle Ob Forest of the Altai Territory]. Vestnik Altaiskogo Gosudarstvennogo Agrarnogo Universiteta. 2016. № 4 (138). P. 105-109.

5. Averianova, E.V.; Shkolnikova, M.N.; Chaplygina I.A. Izuchenie Svoistv Pektina Poluchennogo iz Vtorichnykh Syrevykh Resursov lagodnogo Syria Altaiskogo Kraia [Properties Study of the Pectin Obtained from Secondary Berry Raw Materials of the Altai Territory]. Vestnik KrasGAU. 2016. № 12. P. 118-127.

6. Szajdek, A.; Borowska E.J. Bioactive Compounds and Health-Promoting Properties of Berry Fruits. A Review. Plant Foods Hum Nutr. 2008. № 63. P. 147-156.

7. Pavlova, N.S.. Sbornik Osnovnykh Retseptur Sakharistykh Konditerskikh Izdelii [Basic Recipes Collection of the Sugar Confectionery]. SPb GIORD. 2000. P. 232.

8. Muratova, E.I.; Smolikhina P.M. Reologiya Konditerskikh Mass [Confectionery Mass Rheology]. Monografiya. Tambov: Izd-vo FGBOU VPO “TGTU”. 2013. P. 188 tration of malic and citric organic acids was 8.281 $\mathrm{mg} / \mathrm{l}$ and $23.020 \mathrm{mg} / \mathrm{l}$, respectively. The sample contained minerals (sodium, potassium, magnesium), which allowed to consider this marmalade sample as a product demonstrating functional properties.

Based on the foregoing, we conclude that the large-tonnage waste use of fruit production (berry pomace) in the pastille and marmalade technology allows to receive food ingredient from the secondary raw materials partially solving the problem of pomace disposal and expanding the range of pastille and marmalade products.

\section{Библиографический список}

1. Сафронова И.В., Гольдина И.А., Гайдуль К.В., Козлов В.А. Особенности химического состава брусники обыкновенной и перспективы ее применения в медицине и здоровом питании, // Инновации и продовольственная безопасность. 2015. № 4. С. 63-73.

2. Злобин А.А., Мартинсон Е.А., Оводов Ю.С Антиоксидантная и антимикробная активность пектинов ряда растений европейского севера России // Известия Коми научного центра УрО РАН. 2011. Вып. 3 (7). С. 33-37.

3. Оводов Ю.С. Современные представления о пектиновых веществах // Биоорганическая химия. 2009. № 3 (35). С. 293-310.

4. Малиновских А.А. Влияние уровня освещенности под пологом леса на урожайность брусники в условиях Средне-0бского бора Алтайского края // Вестник Алтайского государственного аграрного университета. 2016. № 4 (138). С. 105-109.

5. Аверьянова Е.В., Школьникова М.Н., Чаплыгина И.А. Изучение свойств пектина, полученного из вторичных сырьевых ресурсов ягодного сырья Алтайского края // Вестник Красноярского государственного аграрного университета. 2016. № 12. C. 118-127.

6. Szajdek A., Borowska E.J Bioactive Compounds and HealthPromoting Properties of Berry Fruits // A Review. Plant Foods Hum Nutr. 2008. № 63. P. 147-156.

7. Сборник основных рецептур сахаристых кондитерских изделий / сост. Н.С. Павлова. СПб.: ГИОРД, 2000. 232 с.

8. Муратова Е.И., Смолихина П.М. Реология кондитерских масс: монография. Тамбов: Изд-во ФГБОУ ВПО «ТГТУ», 2013. 188 с.

\section{Информация 06 авторе / Information about Author}

\section{Shkolnikova,} Marina Nikolaevna

\section{Школьникова}

\section{Марина Николаевна}

Тел./Phone: +7 (343) 221-26-72

E-mail: shkolnikova.m.n@mail.ru
Doctor of Technical Science, Associate Professor, Professor of Food Technology Department Ural State University of Economics 620144, Russian Federation, Ekaterinburg, 8 March St./ Narodnoy Voli St., 62/45

Доктор технических наук, доцент, профессор кафедры технологии питания Уральский государственный экономический университет 620144, Российская Федерация, г. Екатеринбург, ул. 8 Марта/Народной Воли, 62/45 